\title{
Tree species richness enhances stand productivity while stand structure can have opposite effects, based on forest inventory data from Germany and the United States of America
}

\author{
Laura Zeller ${ }^{1^{*}}$, Jingjing Liang ${ }^{2}$ and Hans Pretzsch ${ }^{1}$
}

\begin{abstract}
Background: In recent studies, mixed forests were found to be more productive than monocultures with everything else remaining the same.

Methods: To find out if this productivity is caused by tree species richness, by a more heterogeneous stand structure or both, we analyzed the effects of forest structure and tree species richness on stand productivity, based on inventory data of temperate forests in the United States of America and Germany.

Results: Having accounted for effects such as tree size and stand density, we found that: (I) tree species richness increased stand productivity in both countries while the effect of tree size heterogeneity on productivity was negative in Germany but positive in the USA; (II) productivity was highest at sites with an intermediate amount of precipitation; and (III) growth limitations due water scarcity or low temperature may enhance structural heterogeneity.
\end{abstract}

Conclusions: In the context of forest ecosystem goods and services, as well as future sustainable forest resource management, the associated implications would be:

- Tree species richness is vital for maintaining forest productivity.

- As an optimum amount of precipitation is accompanied by the highest productivity, changes in climatic conditions should be considered when planning.

- Resource limitations enhance structural heterogeneity, which in turn can have positive or negative effects on stand productivity.

Furthermore, we discuss the difficulties encountered when analyzing different national forest inventories and large data sets.

Keywords: Big data, Overyielding, Tree size heterogeneity, Tree species mixing, Climate, Biodiversity-productivity relationship

\footnotetext{
* Correspondence: laura.zeller@tum.de

${ }^{1}$ Center of Life and Food Sciences Weihenstephan, Technical University of

Munich, Hans-Carl-von-Carlowitz-Platz 2, 85354 Freising, Germany

Full list of author information is available at the end of the article
} 


\section{Background}

Economic and political relationships, environmental issues, and the network of supply and demand for wood products and ecosystem services have become more global. Meanwhile, the pressure on forest ecosystems is increasing due to climate change (Schröter et al. 2005; Wohlgemuth 2015) and a growing world population. Therefore, the need for globalizing and connecting forest research from different parts of the world to use synergy effects and combine knowledge is therefore becoming more and more important. Many countries are already advanced in forest research and are conducting national forest inventories to monitor the status, as well as to predict the future development, of forests. The Global Forest Biodiversity Initiative (GFBI) aims to connect the knowledge and data worldwide on forest biodiversity while spreading and using the available data more effectively for sustainable forest ecosystem management (Global Forest Biodiversity Initiative 2016).

The joint analysis of forest structure, tree species richness and stand productivity is becoming more relevant as recent studies have shown the different relationships among these attributes (Bohn and Huth 2017), which can now be analyzed on a global scale thanks to the socalled "big data era" (Lokers et al. 2016).

There are many current silvicultural programs that are restoring, stabilizing, and diversifying forests in terms of tree species and stand structure to render forests more productive, resilient, and sustainable in the long run (Ammer 2008; Knoke et al. 2008). In particular, a broader supply of forest ecosystem goods and services will be provided by more natural forest ecosystems. Not only would the provision of wood products be ensured, but the stabilizing function of water and nutrient cycles, the maintenance of different habitats, possibilities for hunting, the lowering of the risks of fire, wind throw, and land degradation, as well as the recreational and educational functions of forest areas, would also be secured (UN General Assembly 1987; MCPFE 1993; The Montréal Process 2015).

Forest management has been criticized for demolishing forest structure, diversity of habitats, and tree size heterogeneity by focusing only on timber production (Dieler et al. 2017). As counteracting strategy, mixing and structuring forests has become a common measure in the transition of mainly timber-oriented forestry toward more sustainable management. The goal is a multifunctional forestry that ideally covers all ecosystem goods and services while striving to reduce risk (Puettmann et al. 2009; Paquette and Messier 2011; Puettmann et al. 2015; Lindenmayer et al. 2016). Those tendencies, however, raise the question whether the achievement of a wider scope of functions and services would result in a reduction of forest productivity.
Not only is the paradigm of a multi-functional forest reinforcing the interest in the relationship among productivity, species richness, and structural diversity, but also the evidence that species mixing and structural diversity can increase productivity. Liang et al. (2016), for example, found positive relationships between tree species richness and forest productivity on a global scale. Pretzsch et al. (2015, 2017) made the same discovery with long-term mixed-species experimental plots of mixed species. Morin et al. (2014) showed that increasing tree species richness could also increase the continuity of forest productivity over time, as different species respond differently to disturbances, and so, can mitigate drops in productivity. Other researchers have also found positive relationships between forest structure and tree species diversity (Ishii et al. 2004; Hakkenberg et al. 2016) or between forest productivity and biodiversity in general (Paquette and Messier 2011). However, Wang et al. (2016) state that depending on the spatial scale of the analysis, both positive and negative diversityproductivity relationships can be found.

Many concepts of mixing and structuring forests are targeting a diversification at the stand level to provide multiple types of habitats (Dieler 2013). Under which conditions could the combination of tree species diversity and forest structure increase or decrease productivity, is still being debated. Answering this question would enable forest management to explore the advantages and disadvantages, as well as quantify the costs and benefits, of structural diversification. At the tree level, Danescu et al. (2016) showed that structural diversity had a significant influence on tree productivity while species diversity had no effect. At the stand level, however, both species diversity and structural heterogeneity were found to have a positive effect on productivity and ecosystem dynamics. Bourdier et al. (2016) discovered that a negative relationship between tree size heterogeneity and productivity could result from lower light interception and use efficiency in the case of an enhanced stand structure. Others have discovered negative relationships between structural diversity and productivity (Edgar and Burk 2001) in temperate forests or tropical Eucalyptus stands when structural diversity is present, but genetic and species diversity are absent (Soares et al. 2016). Chen and Klinka (2003) however, did not find any relationship between structure and productivity.

To differentiate among structural, diversity and climatic effects when analyzing forest productivity, the interaction between structural diversity and tree species richness, as well as the effects of climatic factors on structural traits, is important. Structural effects may occur only in certain types of mixtures, or within a certain range of temperature or precipitation. A potential overyielding in productivity by mixed forest stands could 
be eliminated or even augmented by structural diversification.

This study collected big data selected from the national forest inventory data in the US national forest inventory FIA (O'Connell et al. 2014), which was provided and unified by GFBI, as well as in the German national forest inventory BWI (BMEL - Bundesministerium for Ernährung und Landwirtschaft 2014). The aim of this study was to discover how forest productivity is determined by tree species richness, climate and forest structure, i.e., tree size heterogeneity. Productivity was defined as the mean annual increment of the stem volume of a forest stand in $\mathrm{m}^{3} \cdot \mathrm{ha}^{-1} \cdot \mathrm{yr}^{-1}$. Forest structure was quantified by indices based on diameter at breast height, which was available for all sample plots. The location of each plot and climatic characteristics were also included in the analysis. The effect of increasing temperature can have a mainly positive effect on forest productivity, as long as the water supply is not decreasing due to the higher temperature, as in the process of evapotranspiration (Yang 2005; Boivenue and Running 2006). Chertov (2010) suggests that productivity is increasing in times of global warming. Thus, climatic conditions should thus be considered when examining the effects of tree species mixing and structural diversification on productivity.

In regard to the above-mentioned background, we formulated the following questions that were to be answered by this study:

QI: How is forest productivity dependent on tree species richness and tree size heterogeneity when other effects, such as tree size and stand density, have been accounted for?

QII: How is forest productivity influenced by temperature and precipitation?

QIII: Do limitations to growth resulting from water scarcity or low temperatures enhance structural heterogeneity?

\section{Material and methods \\ Material \\ Inventory data}

The data set used in this study partly consists of nearly 56,000 inventory plots of the third national forest inventory data of Germany (BMEL - Bundesministerium for Ernährung und Landwirtschaft 2014). Additionally, 576,000 plots belonging to the national forest inventory of the United States of America were used ( $\mathrm{O}^{\prime}$ Connell et al. 2014). All plots were located in the conterminous USA, because the Pacific islands and Alaska represent climatic zones quite different from the rest of the country. Different conditions along a climatic gradient for temperate forests on both the North American and the European continents were represented.

Both inventories were conducted using the angle count sampling method and only trees with a diameter of $7 \mathrm{~cm}$ or more at breast height were included. For Germany, we used the third national forest inventory from 2012, which was the latest inventory conducted (BMEL - Bundesministerium for Ernährung und Landwirtschaft 2014). The latest USA national inventory data, taken between 2012 and 2016, was used (O'Connell et al. 2014).

Both inventories contain only approximate coordinates due to national legislation protecting the privacy of forest owners. The real locations of the inventory plots can differ by up to $1 \mathrm{~km}$ in Germany (Henning 2016) and by $0.8-11.6 \mathrm{~km}$ in the USA (O'Connell et al. 2014).

The German inventory is based on a $4 \mathrm{~km} \times 4 \mathrm{~km}$ grid (base grid), but a smaller grid size $(2.83 \mathrm{~km} \times 2.83 \mathrm{~km}$ or $2 \mathrm{~km} \times 2 \mathrm{~km}$ ) was used in some regions. Each inventory plot is a square of $150 \mathrm{~m} \times 150 \mathrm{~m}$, of which each corner represents a subplot when an angle count sampling with a counting factor of 4 is applied. We treated the independent subplots as individual plots, as the subplots could be part of different forest types, and so, cannot be correlated.

The US inventory plots are 0.04 ha in size and are placed on a hexagonal grid so that one plot represents every 2428 ha of forested land ( $\mathrm{O}^{\prime}$ Connell et al. 2014). Each plot consists of a cluster of four circular subplots spaced out in a fixed pattern. As most tree measurements are taken at the level of the subplots, we also treated the US inventory subplots as individual plots. Spatial correlation, in general, was covered in the generalized additive model.

US inventory plots having large stand density index $(S D I)$ values of more than 5000 were omitted from the analysis because the high numbers had obviously been created by the calculation method of SDI, which used small sample plots and deduced the number of stems per hectare. The maximum SDI of the German data set was just above 5000, so that we did not set an additional limit.

\section{Productivity}

For the German data, the tree and stand growths from the national inventories, BWI II and BWI III, collected in 2002 and 2012, respectively, were used. Stand volumes in $\mathrm{m}^{3} \cdot \mathrm{ha}^{-1} \cdot \mathrm{yr}^{-1}$ were calculated for the second and the third inventories, as well as for the group of trees present in the third inventory, but not in the second. The stand volume of the second inventory was subtracted from that of the third, then the volume of the removal stand was added. The resulting values in $\mathrm{m}^{3} \cdot$ ha ${ }^{-1} \cdot \mathrm{yr}^{-1}{ }^{-1}$ divided by the length of time between the inventories represent the productivity of each stand.

Stand productivity for the US plots was derived from the periodic annual increment growth between the two inventories for the US inventory plots where more than one inventory was conducted (Liang et al. 2016). The original worldwide map of stand productivity was 
downscaled from a $53 \mathrm{~km} \times 53 \mathrm{~km}$ to a $3 \mathrm{~km} \times 3 \mathrm{~km}$ resolution using geospatial interpolation (Liang et al. work-in-progress). For improved accuracy, we extracted productivity values from the downscaled map to the locations of the US inventory plots used in this analysis.

\section{Climate data}

The annual precipitation and mean annual temperature for 1970-2000 from the WorldClim data Version 2 were used with a resolution of 2.5 min (Fick and Hijmans 2017).

The mean annual temperatures of the inventory plots for $1970-2000$ were $8.3^{\circ} \mathrm{C}$ and $11.6{ }^{\circ} \mathrm{C}$ for the Germany and US data, respectively. The mean annual precipitation were 830 and $1054 \mathrm{~mm}$ for the German and US plots, respectively (Tables 1 and 2).

\section{Tree and stand characteristics}

The data sets of the tree and stand characteristics in Germany and the USA are presented in Tables 1 and 2, respectively.

Species richness $R$ is lower in Germany than in the USA due to, firstly, the lower number of existing tree species, and secondly, the very common one- and twospecies stands in Germany. The mean diameter $d$ and quadratic mean diameter $d q$ are higher in Germany, possibly due to a higher stand age or different silvicultural treatment as compared to the inventory plots in the USA. Tree size heterogeneity $C V d$ is higher in the USA, whereas the $S D I$ is higher in Germany. The overall climate is warmer and wetter in the USA, but productivity is higher in Germany.

\section{Methods}

\section{Quantifying stand structure and tree species richness}

To quantify forest structure, the quadratic mean diameter $(d q)$, coefficient of variation of the tree diameter at breast height $(C V d)$, and stand density index $(S D I)$ were calculated for each inventory plot (Eq. (1)). Single tree positions that would allow for the calculation of the

Table 1 Descriptive data of inventory plots (Germany)

\begin{tabular}{lllllllll}
\hline & $R$ & $d$ & $d q$ & $C V d$ & SDI & Temp & Precip & $P$ \\
\hline mean & 2.02 & 27.14 & 28.59 & 0.32 & 1158.02 & 8.32 & 842.12 & 12.24 \\
sd & 1.06 & 12.2 & 12.18 & 0.19 & 603.3 & 0.93 & 250.52 & 8.96 \\
se & 0 & 0.05 & 0.05 & 0 & 2.54 & 0 & 1.05 & 0.04 \\
$\min$ & 1 & 7 & 7 & 0 & 38.67 & 0.31 & 467 & 0 \\
$\max$ & 9 & 165 & 165 & 1.46 & 5375.02 & 10.83 & 1984 & 103.59 \\
n & 56,449 & & & & & &
\end{tabular}

$R$ number of species, $d$ diameter at breast height $(\mathrm{cm}), d q$ quadratic mean diameter $(\mathrm{cm}), C V d$ coefficient of variation of diameter, SDI stand density index, Temp mean annual temperature, Precip annual precipitation, $P$ stand productivity $\left(\mathrm{m}^{3} \cdot \mathrm{ha}^{-1} \cdot \mathrm{yr}^{-1}\right)$
Table 2 Descriptive data of inventory plots (USA)

\begin{tabular}{lllllllll}
\hline & $R$ & $d$ & $d q$ & $C V d$ & SDI & Temp & Precip & $P$ \\
\hline mean & 4.67 & 19.91 & 21.97 & 0.44 & 522.63 & 11.56 & 1055.95 & 6.22 \\
sd & 2.82 & 8.17 & 8.81 & 0.19 & 464.31 & 5.6 & 357.02 & 0.64 \\
se & 0 & 0.01 & 0.01 & 0 & 0.61 & 0.01 & 0.47 & 0 \\
$\min$ & 1 & 7.11 & 7.11 & 0 & 0.16 & -2.88 & 56 & 4.01 \\
$\max$ & 21 & 169.93 & 169.93 & 1.9 & 4998.34 & 24.57 & 3353 & 8.02 \\
$n$ & & & \multicolumn{7}{c}{576,415} \\
\end{tabular}

$R$ number of species, $d$ diameter at breast height $(\mathrm{cm}), d q$ quadratic mean diameter $(\mathrm{cm}), C V d$ coefficient of variation of diameter, $S D I$ stand density index, Temp mean annual temperature, Precip annual precipitation, $P$ stand productivity $\left(\mathrm{m}^{3} \cdot \mathrm{ha}^{-1} \cdot \mathrm{yr}^{-1}\right)$

spatial structure indicators were not available for the data sets used in this study.

Quadratic mean diameter $(\boldsymbol{d} q)$ As the inventory data were angle count samples, $d q$ was calculated by:

$$
d q=\sqrt{\frac{\sum_{i=1}^{N} d_{i}^{2} \cdot n_{i}}{\sum_{i}^{N} n_{i}}}
$$

Equation 1 includes the number of trees counted per inventory plot $N$, the diameter at breast height of the $i^{\text {th }}$ tree per plot, $d_{i}$, and the number of stems per ha represented by the $i^{\text {th }}$ tree, $n_{i}$.

Stand density index (SDI) The SDI by Reineke (1933) was calculated using a plot's total stem number per ha, $N_{p}=\sum_{i=1}^{N} n_{i}$, and $d q$ :

$$
S D I=N_{p} \cdot\left(\frac{25}{d q}\right)^{-1.605}
$$

$S D I$ was used in this study because it produces stand density information that allows for the comparison of forest stands of any age or stage of development. We used the generalized allometric exponent by Reineke (1933), as species-specific exponents were not available for many of the included tree species.

Coefficient of variation of tree diameters $(\boldsymbol{C V d})$ The coefficient $C V d$, of variation of tree diameters relates their standard deviation $s d$ to their arithmetic mean $\bar{d}$ :

$$
C V d=s d \bar{d}
$$

This coefficient serves as a relative measure of tree size heterogeneity per inventory plot. However, due to angle count sampling, the representative stem number $n_{i}$, of each tree $i$ per inventory plot had to be taken into account when calculating $s d$ and $\bar{d}$ : 


$$
\begin{aligned}
& \bar{d}=\frac{\sum_{i=1}^{N} d_{i} \cdot n_{i}}{\sum_{i=1}^{N} n_{i}} \\
& s d=\sqrt{\frac{\sum_{i=1}^{N}\left(d_{i}-\bar{d}\right)^{2} \cdot n_{i}}{\sum_{i=1}^{N} n_{i}-1}}
\end{aligned}
$$

Equations (3), (3a) and (3b) use the same notation meanings as does Eq. (1).

Tree species richness Tree species richness as used in this study is the absolute number of different tree species on a plot (Pretzsch 2009, p. 279).

\section{Generalized additive model (GAM)}

To investigate the effect of climate on forest structure, we used parts of the same model but exchanged productivity as the dependent variable with the coefficient of variation of diameter at breast height.

Model function for QI + QII To answer the research questions, QI (the effects of tree species richness and stand structure on stand productivity and QII (the effect of climate on stand productivity), we formulated a GAM function (4):

$$
\begin{aligned}
P_{i}= & a+f_{1}\left(\text { Lon }_{i},, \text { Lat }_{i}\right) \\
& +f_{2}\left(\text { Temperature }_{i}, \text { Precipitation }_{i}\right) \\
& +f_{3}\left(S D I_{i}, d q_{i}\right)+f_{4}\left(R_{i},, C V d_{i}\right)+\varepsilon_{i}
\end{aligned}
$$

This model seeks to explain stand productivity $P$ as a function of species richness $R$, the stand structural heterogeneity expressed by the diameters' coefficient of variation, $C V d$, stand density, $S D I$, mean tree size, represented by mean tree diameter, $d q$, mean annual temperature and annual precipitation. The index $i$ represents an inventory point, $\varepsilon$ represents the remaining errors, $a$ is the model's intercept, which is to be estimated, and $f_{1}, \ldots, f_{4}$ are non-linear smoothers to be fitted. These smoothers are two-dimensional, i.e., they cover the possible interactions between two explanatory variables each. Here, smoother $f_{1}$ is based on geographical longitude Lon and latitude Lat, and is intended to cover the effects of unobservable influence variables connected with the geographical position of a plot. Smoother $f_{2}$ covers the climate effect, $f_{3}$ covers a stand density effect, which may be size-dependent. Such effects would bias the findings on the influence variables of interest if the smoothers were not used. The variables of interest, accounted for by the smoother $f_{4}$, are the effects of tree species richness and structural diversity.

To check for the effect of climate on forest structure (QIII), we used a similar function but with the coefficient of variation of diameter as the dependent variable.
Finally, we set up the model function (5):

$$
\begin{aligned}
\text { CVd }_{i}= & a+f_{1}\left(\text { Lon }_{i},, \text { Lat }_{i}\right) \\
& +f_{2}\left(\text { Temperature }_{i}, \text { Precipitation }_{i}\right) \\
& +f_{3}\left(\text { SDI }_{i},, d q_{i}\right)+f_{4}\left(R_{i}\right)+\varepsilon_{i}
\end{aligned}
$$

Equation (5) uses the same meaning of notation as does Eq. (4). The smoothers, $f_{1}$ for geographical longitude and latitude, $f_{2}$ for climate effects, and $f_{3}$ for a potentially size-dependent stand density effect, were included in the model to cover those effects not explained by species richness $R$.

All variables tested in the GAMs of our study were significant. We compared the full model functions to their reduced versions by eliminating the smoothers. In our case, the full model functions yielded lower AIC values and higher $R^{2}$ as compared to the reduced versions, and so, were thus selected as the final model functions.

For our analysis we set up the generalized additive models (GAM) (Crawley 2007; Zuur 2009) using the mgcv package (Wood 2011) in R (R Development Core Team 2008).

\section{Results}

\section{Statistical analysis}

When applying our models, the full model versions always yielded the lowest AIC, and so, were chosen as the final models. To interpret the GAM results, twodimensional heat maps were used and the effect of each variable was isolated while all other variables were set to their mean values. When testing each variable by varying its value from the minimum to the maximum, its isolated effects on the dependent variable were observed.

QI: How is forest productivity influenced by tree species richness and tree size heterogeneity?

\section{Germany}

Location The effect of location covered by the interaction term for longitude and latitude showed mostly a strong positive effect of latitude on stand productivity. Our model showed that stand productivity increased from $\sim 10 \mathrm{~m}^{3} \cdot \mathrm{ha}^{-1} \cdot \mathrm{yr}^{-1}$ to $\sim 13 \mathrm{~m}^{3} \cdot \mathrm{ha}^{-1} \cdot \mathrm{yr}^{-1}$ along the range of $47.33^{\circ} \mathrm{N}$ up to $54.92^{\circ} \mathrm{N}$ (Fig. 1b), indicating that productivity was increasing toward the northern part of Germany (Fig. 2a).

Stand density and tree size $S D I$ clearly explains part of the variation in stand productivity. An increase in SDI up to 2000 stems $\cdot \mathrm{ha}^{-1}$ (where most of the data was represented) made productivity rise from 7 to $17 \mathrm{~m}^{3} \cdot$ ha ${ }^{-1}$.yr. ${ }^{-1}$ (Fig. 1e). Tree size $(d q)$ had only a small negative effect (Fig. 2c). For an increase in $d q$ from 0 to $100 \mathrm{~cm}$, 

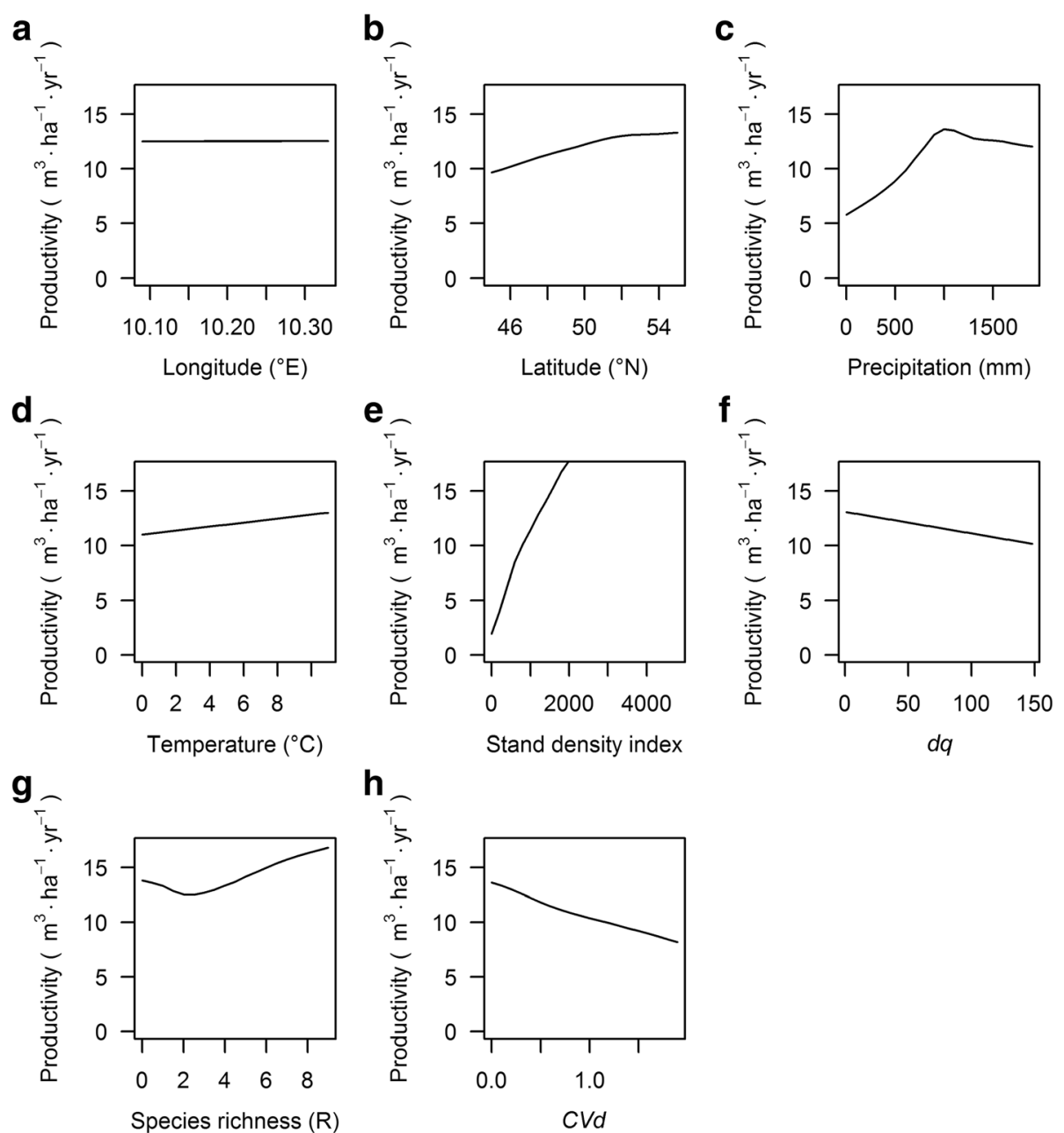

Fig. 1 Effects of longitude (a), latitude (b), annual precipitation (c), mean annual temperature (d), tree species richness (e), and tree size heterogeneity (f) on stand productivity of German inventory plots. Each variable was tested on its own while other variables were set to the mean

the effect on stand productivity explains a variation of $\sim$ $3 \mathrm{~m}^{3} \cdot \mathrm{ha}^{-1} \cdot \mathrm{yr}^{-1}$ in productivity (Fig. 1f).

Species richness and structure For up to two different species, stand productivity decreased with increasing tree species richness from about 14 to about $12 \mathrm{~m}^{3} \cdot \mathrm{ha}$ ${ }^{-1} \cdot \mathrm{yr}^{-1}{ }^{-1}$, which means that inventory plots with two species on average had a $\sim 2 \mathrm{~m}^{3} \cdot \mathrm{ha}^{-1} \cdot \mathrm{yr}^{-1}$ lower stand productivity than did monocultures. For more than three tree species the trend was the opposite and stand productivity increased again up to $\sim 16 \mathrm{~m}^{3} \cdot \mathrm{ha}^{-1} \cdot \mathrm{yr}^{-1}$ for stands with eight tree species (Figs. 1g and 2d).

Since the mean number of tree species in the German plots was two, stands with a high number of species were represented only by a small sample size. The effect of structural heterogeneity was negative. With a mean $C V d$ of $\sim 0.32$ and most of the data occurring around this value, the valid part of the model still describes a negative effect of structure on stand productivity by $\sim 2 \mathrm{~m}^{3} \cdot \mathrm{ha}^{-1} \cdot \mathrm{yr}^{-1}$ along the range of $C V d$ from 0 to $\sim 1.0$, covering most of the data (Figs. $1 \mathrm{~h}$ and $2 \mathrm{~d}$ ).

The least productive combination was a low number of tree species with a high tree size heterogeneity. Additional tree species could partly mitigate the negative effect of tree size heterogeneity on stand productivity.

\section{USA}

Location Most of the productivity in our model was determined by location and climatic conditions, which together explained up to $\sim 4 \mathrm{~m}^{3} \cdot \mathrm{ha}^{-1} \cdot \mathrm{yr}^{-1}$ of the variation among the plots. From the western part $\left(-124.7^{\circ} \mathrm{E}\right)$ to the most eastern part of the conterminous USA $\left(-67^{\circ}\right.$ E), productivity increased from $\sim 5$ to more than $6 \mathrm{~m}^{3} \cdot$ ha ${ }^{-1} \cdot$ yr. $^{-1}$ (Fig. 3a). Latitude explained a drop of more than $1.5 \mathrm{~m}^{3} \cdot \mathrm{ha}^{-1} \cdot \mathrm{yr}^{-1}$ in productivity from the most southern 

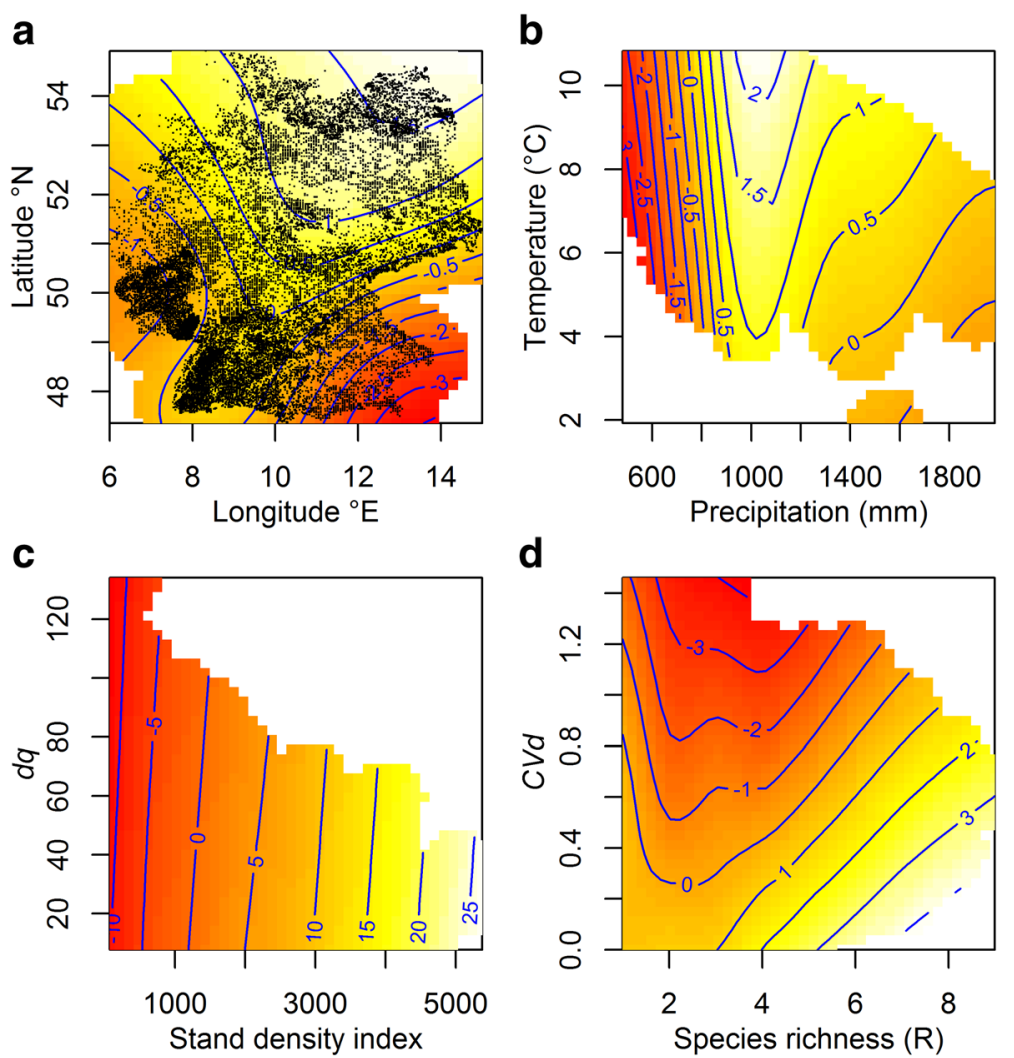

Fig. 2 Effects of location $(\mathbf{a})$, climate $(\mathbf{b})$, tree species richness and tree size heterogeneity $(\mathbf{c})$, and stand density and tree size (d) on stand productivity of German inventory plots. Yellow = positive effect on productivity, red = negative effect on productivity. Blue contour lines show where the function has a constant value

part $\left(25.07^{\circ} \mathrm{N}\right)$ to the most northern part $\left(49.35^{\circ} \mathrm{N}\right)$ (Fig. 3b). Productivity was, therefore, highest in the southeastern part of the US (Fig. 4a).

Stand density and tree size Tree size had a small but positive effect and explained about $0.2 \mathrm{~m}^{3} \cdot \mathrm{ha}^{-1} \cdot \mathrm{yr}^{-1}$ of the variation in stand productivity (Fig. 3f). Stand density had a small positive influence on stand productivity up to an $S D I$ of $\sim 500$. For an $S D I>500$, the effect was contrary (Fig. 3e). Figure $4 \mathrm{c}$ shows the combination of both effects.

Species richness and structure The number of species showed a small but positive effect on stand productivity for up to 10 different tree species. For more than 10 species the relationship between species richness and stand productivity was found to be negative (Fig. $3 g$ ). Tree size heterogeneity $d q$ had a slightly positive influence on stand productivity (Fig. 3h). As most of the variation was already by location and climatic influence, the effects of tree species richness and tree size heterogeneity were small but still evident. The combination of both effects is shown in Fig. 4c.
QII: How is forest productivity influenced by precipitation and temperature?

\section{Germany}

Stand productivity was mainly enhanced by, and so, is positively correlated with the amount of precipitation. For up to $1000 \mathrm{~mm}$, the effect of precipitation was clearly positive and explained productivity's increase from $\sim 8$ to $13 \mathrm{~m}^{3} \cdot \mathrm{ha}^{-1} \cdot \mathrm{yr}^{-1}$ with annual precipitation's increase from $\sim 400$ to $1000 \mathrm{~mm}$. For more than $1000 \mathrm{~mm}$ per year, the influence of precipitation on stand productivity was reverse, thus negative (Fig. 1c). Mean annual temperature had a positive effect on productivity. By increasing mean annual temperature from $0{ }^{\circ} \mathrm{C}$ to $10{ }^{\circ} \mathrm{C}$, stand productivity increased from $\sim 11$ to $\sim 13 \mathrm{~m}^{3} \cdot \mathrm{ha}^{-1} \cdot \mathrm{yr}^{-1}$, explaining up to $2 \mathrm{~m}^{3} \cdot \mathrm{ha}^{-1} \cdot \mathrm{yr}^{-1}$ of the variation in the productivity of the German plots (Fig. 1d). The main finding concerning climate was the negative effect of a dry climate especially in combination with high temperatures. Only in the case of an optimum amount of annual precipitation did temperature show positive effects (Fig. 2b). 
a

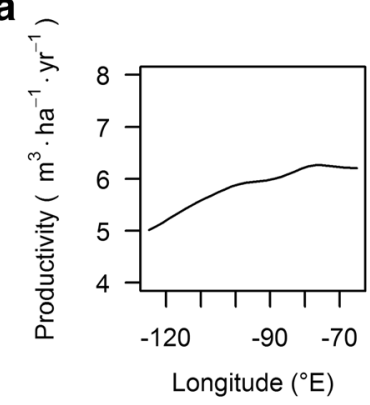

d

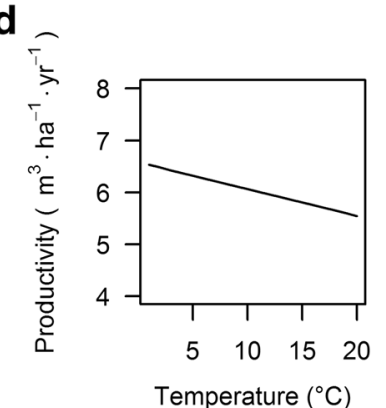

g

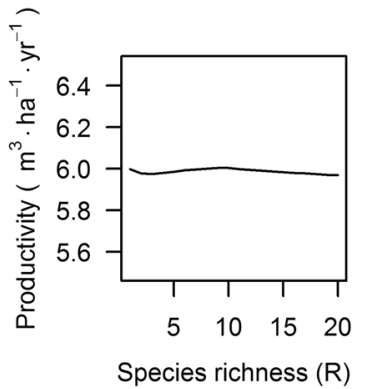

b

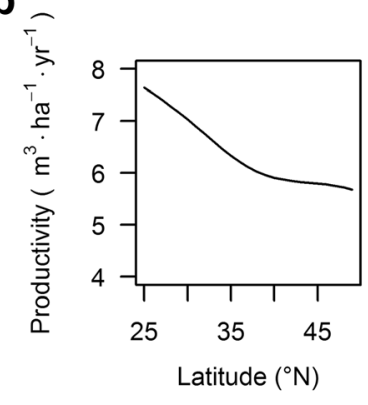

e.

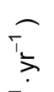

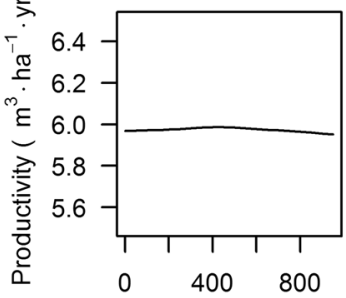

Stand density index

h

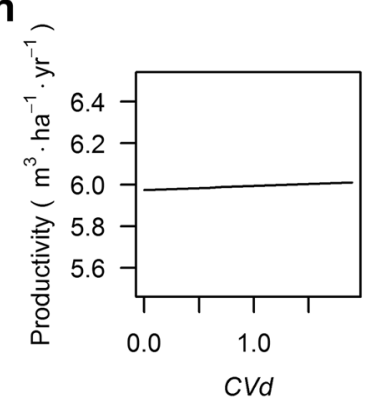

c

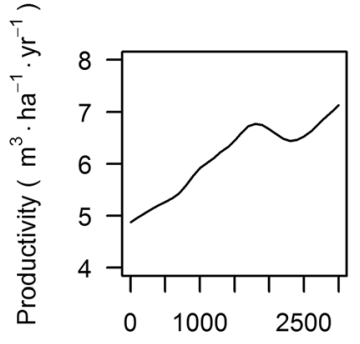

Precipitation (mm)

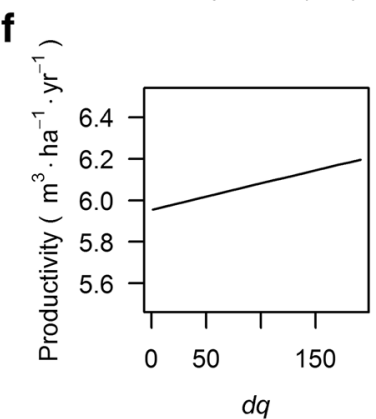

Fig. 3 Effects of longitude (a), latitude (b), annual precipitation (c), mean annual temperature (d), tree species richness (e), and tree size heterogeneity $(\mathbf{f})$ on stand productivity of US inventory plots. Each variable was tested on its own while other variables were set to the mean

USA

Precipitation was the main climatic driver for stand productivity in the USA, leading to an increase in stand productivity from 5 to nearly $7 \mathrm{~m}^{3} \cdot \mathrm{ha}^{-1} \cdot \mathrm{yr}^{-1}$ along the range of precipitation up to $2000 \mathrm{~mm}$ (Fig. 3c). Temperature had a negative effect. Along the range from $\sim 6.5{ }^{\circ} \mathrm{C}$ to $20{ }^{\circ} \mathrm{C}$, stand productivity decreased from 6.5 to $5.5 \mathrm{~m}^{3} \cdot \mathrm{ha}^{-1} \cdot \mathrm{yr}^{-1}$ (Fig. 3d). Our model showed that a warm and dry climate was negatively influencing stand productivity (Fig. 4b).

QIII: Do growth limitations due to water scarcity or low temperatures enhance structural heterogeneity?

\section{Germany}

Location Neither longitude nor latitude had any large effect on tree size heterogeneity, meaning that stand structure was rather homogeneous from south to north. Only toward the most northern part of Germany did tree size heterogeneity show a slight increase (Figs. 5a, b and $6 a$ ).

Climate Annual precipitation and mean annual temperature had small positive effects on tree size heterogeneity $C V d$. Increasing precipitation from $\sim 600$ to $1400 \mathrm{~mm} \cdot \mathrm{yr}^{-1}{ }^{-1}$ showed an increase in $C V d$ from $\sim 0.35$ to 0.4 (Fig. 5c). $C V d$ was increasing from 0.26 to 0.3 along a range of a mean annual temperatures from $0{ }^{\circ} \mathrm{C}$ up to $10{ }^{\circ} \mathrm{C}$ (Fig. 5d). In Germany, the analyzed forest inventory plots were more heterogeneous in tree size at warm and wet sites (Fig. 6b).

Stand density and tree size $S D I$ only showed a positive effect on tree size heterogeneity up to an SDI of $\sim 500$ (Fig. 5e). With increasing tree size $d q$ from 10 to $80 \mathrm{~cm}$, tree size heterogeneity decreased from $\sim 0.45$ to $\sim 0.2$ (Fig. 5f), indicating that stands with larger trees on average were less heterogeneous in tree size. Forest stands 

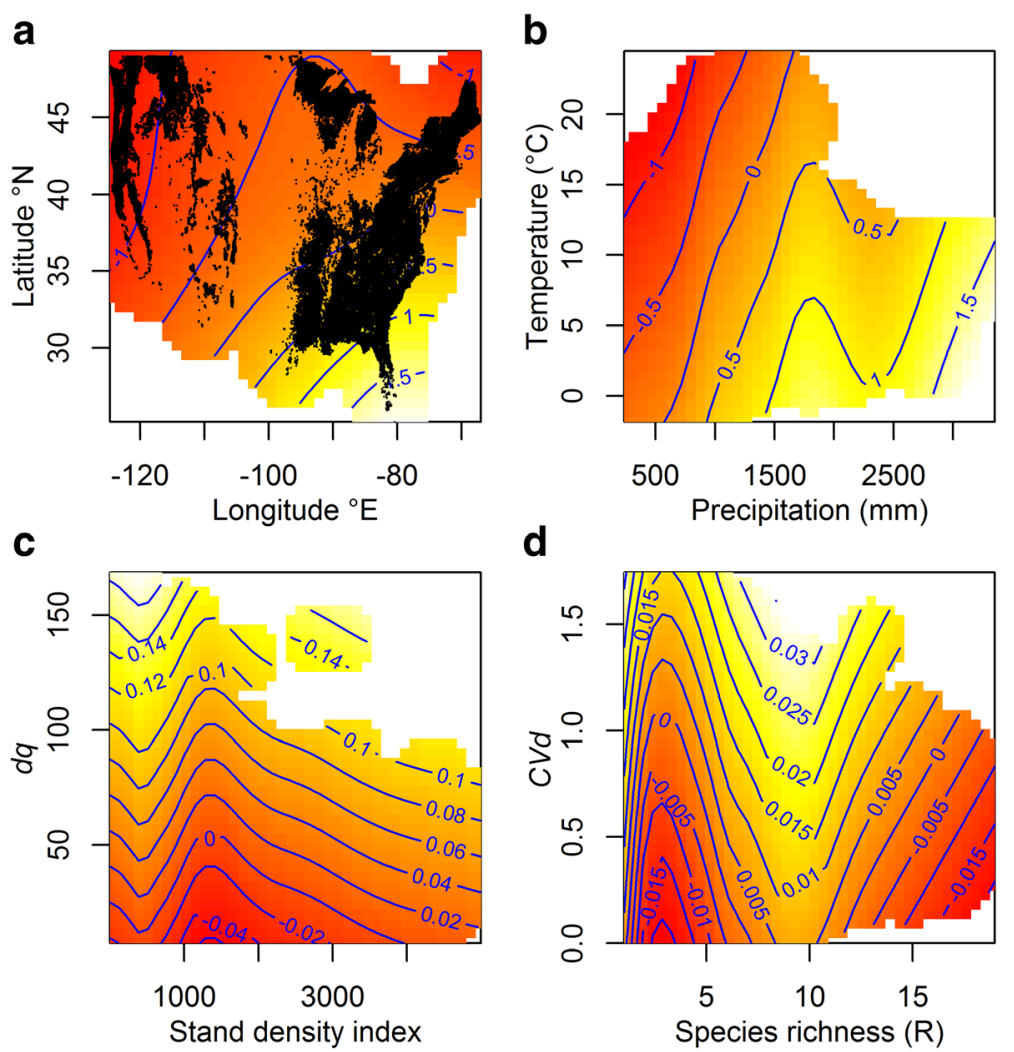

Fig. 4 Effects of location (a), climate (b), tree species richness and tree size heterogeneity (c), and stand density and tree size (d) on stand productivity of US inventory plots. Yellow = positive effect on productivity, red = negative effect on productivity. Blue contour lines show where the function has a constant value

with a combination of a high $S D I$ and a lower $d q$ showed the highest tree size heterogeneity (Fig. 6c).

Tree species richness The number of species was clearly positively related to stand heterogeneity $\mathrm{CVd}$, which increased from 0.3 up to 0.6 along a range of species richness of 2 to $\sim 7$ species per plot (Fig. 5g). For more than $\sim 8$ tree species, species richness had a negative effect on tree size heterogeneity. The graphical representation of species richness $R$ as a single variable shows its effect on $C V d$ on the $y$-axis (Fig. 6d).

\section{USA}

Location Structural heterogeneity increased from the eastern part to the western parts of the USA with a coefficient of variation $(C V d)$ of 0.4 to about 0.6 (Fig. 7a). The effect of location on a north-south gradient had a lower effect on tree size heterogeneity, showing the highest tree size heterogeneity between $35^{\circ} \mathrm{N}$ and $40^{\circ} \mathrm{N}$ (Fig. 7b). On sample plots that were more northerly, stand structure was less heterogeneous. The overall variation explained by location is shown in Fig. 8a.
Climate The effect of climate was not very pronounced but a slightly lowering effect of annual precipitation on structure was found (Fig. 7c). Mean annual temperature did not show any clear effect on tree size heterogeneity CVd (Fig. 7d). The combination of precipitation and temperature highlights the strong role of precipitation as a driver of tree size heterogeneity (Fig. 8b). Thus, structural heterogeneity was highest at sites with low precipitation.

Stand density and tree size Stand density and tree size heterogeneity $C V d$ were positively correlated. $C V d$ increased from $\sim 0.30$ to $\sim 0.7$ for an increase in $S D I$ along a range from 0 up to 5000 (Figs. 7e and 8c). Tree size had a slightly negative effect on $C V d$ (Figs. $7 \mathrm{f}$ and 8c).

Species richness The number of tree species had a vital effect on tree size heterogeneity. An increase in tree species richness from 1 to 20 led to a more heterogeneous stand structure $C V d$, increasing from $\sim 0.4$ to $\sim 0.6$ (Fig. $7 \mathrm{~g})$. The single effect of species richness $R$ on $C V d$ is presented on the $y$-axis (Fig. 8d).

The results of using the GAMs are presented in Tables 3 and 4. They show the intercept a of the model function, its standard error, the significance of each 

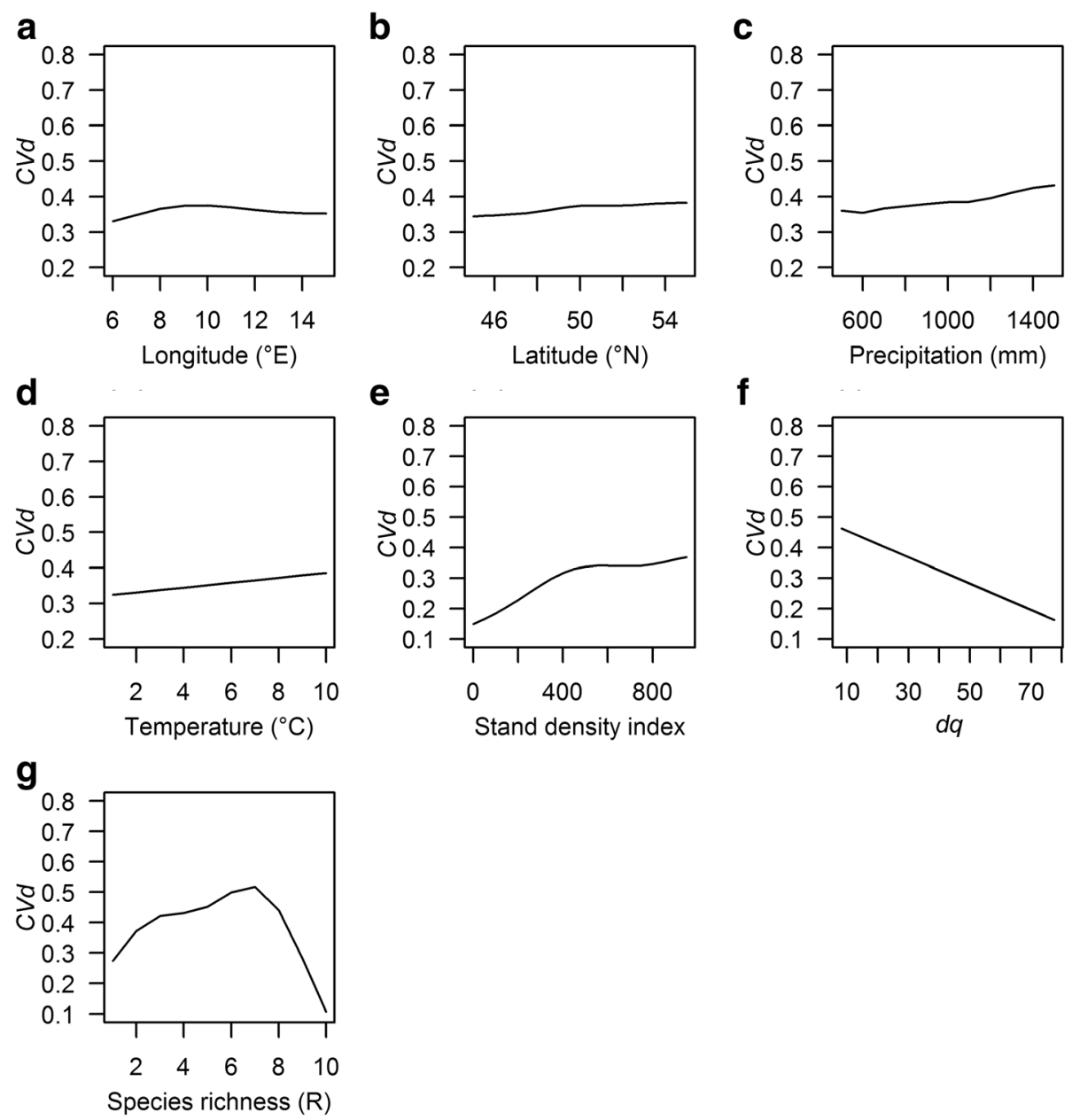

Fig. 5 Effects of longitude (a), latitude (b), annual precipitation (c), mean annual temperature $(\mathbf{d})$, tree species richness (e), and stand density (f) on tree size heterogeneity of German inventory plots. Each variable was tested on its own while other variables were set to the mean

model, and the R-square (adjusted). Based on AIC, the full versions of the models were selected.

\section{Discussion}

\section{Stand productivity}

Tree size heterogeneity did not have a stronger positive effect on stand productivity than did tree species richness (QI), which was found to influence stand productivity, as well as tree size heterogeneity, in both the German and US inventory plots. In Germany, structure had a negative effect on stand productivity, whereas, in the USA, structurally more diverse stands were slightly more productive.

In the German inventory plots, we found the lowest stand productivity in the case of two tree species. Comparing monocultures to the two-species mixed stands showed lower productivity for the two-species plots, as explained by others (Binkley 1984; Chen and Klinka 2003), possibly due to the more efficient use of resources by the highly productive monocultures. For more than two tree species, a positive biodiversity-productivity relationship appeared. For the US data set, there was a similar trend seen of increasing productivity with increasing tree species richness. Despite the findings of Binkley (1984) and Chen and Klinka (2003), the US inventory plots having up to 10 different tree species showed an increase in productivity. The positive relationship of tree species richness with stand productivity found in US and German inventory plots with more than two tree species matches the positive biodiversityproductivity relationships described by Kelty (2006), Gamfeldt et al. (2013), Vilà et al. (2013), Pretzsch et al. (2015), Liang et al. (2016) and Pretzsch et al. (2017).

We wanted to test the interaction of tree species richness and structure in particular. Silva Pedro et al. (2017) found that species composition and stand structure are strongly connected, and that their combination could quite influence forest productivity. In the case of a lower productivity due to a lower crown cover in mixedspecies stands, a more heterogeneous stand structure 


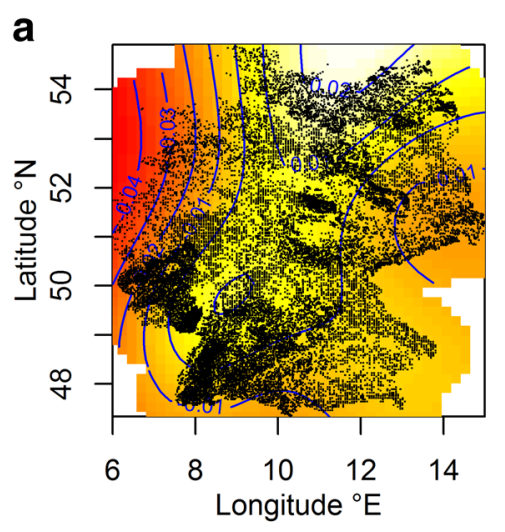

C

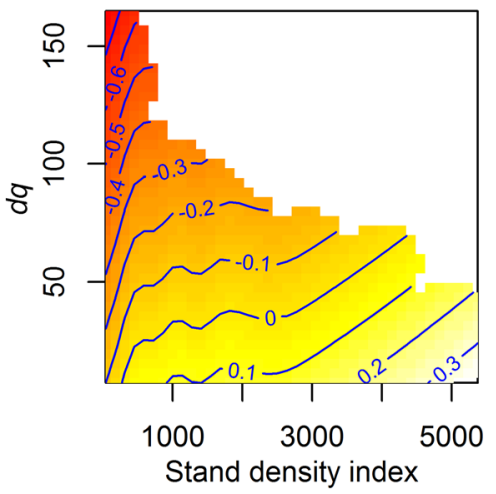

b

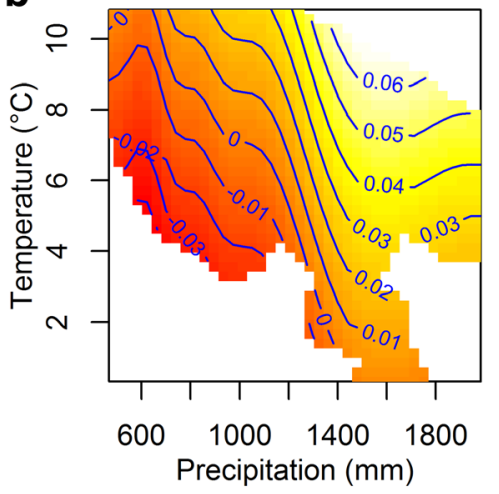

d

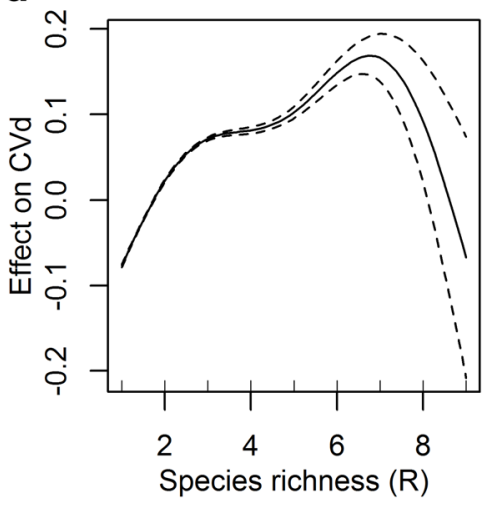

Fig. 6 Effects of location (a), climate (b), and stand density and tree species richness (c) on tree size heterogeneity of German inventory plots. Yellow = positive effect on productivity, red = negative effect on productivity. Blue contour lines show where the function has a constant value

could mitigate the potential loss. In our case, as most of the variation in productivity among the sample plots was already explained by location and climate, for the US inventory plots, effects of species and structure were very small but still present. This finding matched those by Bohn and Huth (2017), who had discovered a positive correlation between structure and productivity. Potential benefits of a higher structural heterogeneity, which leads to overyielding can result from more efficient use of resources through multiple forest layers and a better exploitation of niches. However, contrary results were found for the German inventory plots. The negative effect of structure on stand productivity was strongest on stands with about two to four tree species. Mitigated by tree species richness, mono-specific stands and stands with more than four tree species experienced weaker negative effects of structure. Similar trends were also found by Bourdier et al. (2016), who show that tree size heterogeneity would also decrease productivity, depending on the shade-tolerance of the tree species. Also, Luu et al. (2013) and Soares et al. (2016) reported a negative effect of tree size heterogeneity on stand productivity.

Stand productivity can also be negatively or positively correlated with stand density (Uhl et al. 2015). Stand density and tree size were, therefore, considered in our model. In the German plots, productivity was positively correlated with stand density, whereas the effect of tree size was very small. In the US plots, the influence of stand density on productivity was less clear and tree size did not show any effect. A lower mean stand density and lower productivity in the US plots compared to a higher stand density and a higher stand productivity in the German plots is in line with findings of higher yields in mixed stands resulting from a higher stand density (Pretzsch and Biber 2016).

Explaining the opposite effects of structure on stand productivity in Germany and the USA, we hypothesize that the two countries are located along a gradient concerning latitude, annual precipitation, temperature, and also productivity, and structure. Possibly, the inventory plots from the two inventories are at different development stages with consequently different structureproductivity relationships. Tree size heterogeneity, here $C V d$, in the German inventory plots (0.32) was already lower than in the US plots (0.44), and stand productivity was higher in Germany (12.24) than in the USA (6.22). Precipitation and temperature were lower in Germany $\left(842 \mathrm{~mm}, 8.3^{\circ} \mathrm{C}\right)$ than in the USA $\left(1056 \mathrm{~mm}, 11.6{ }^{\circ} \mathrm{C}\right)$. 

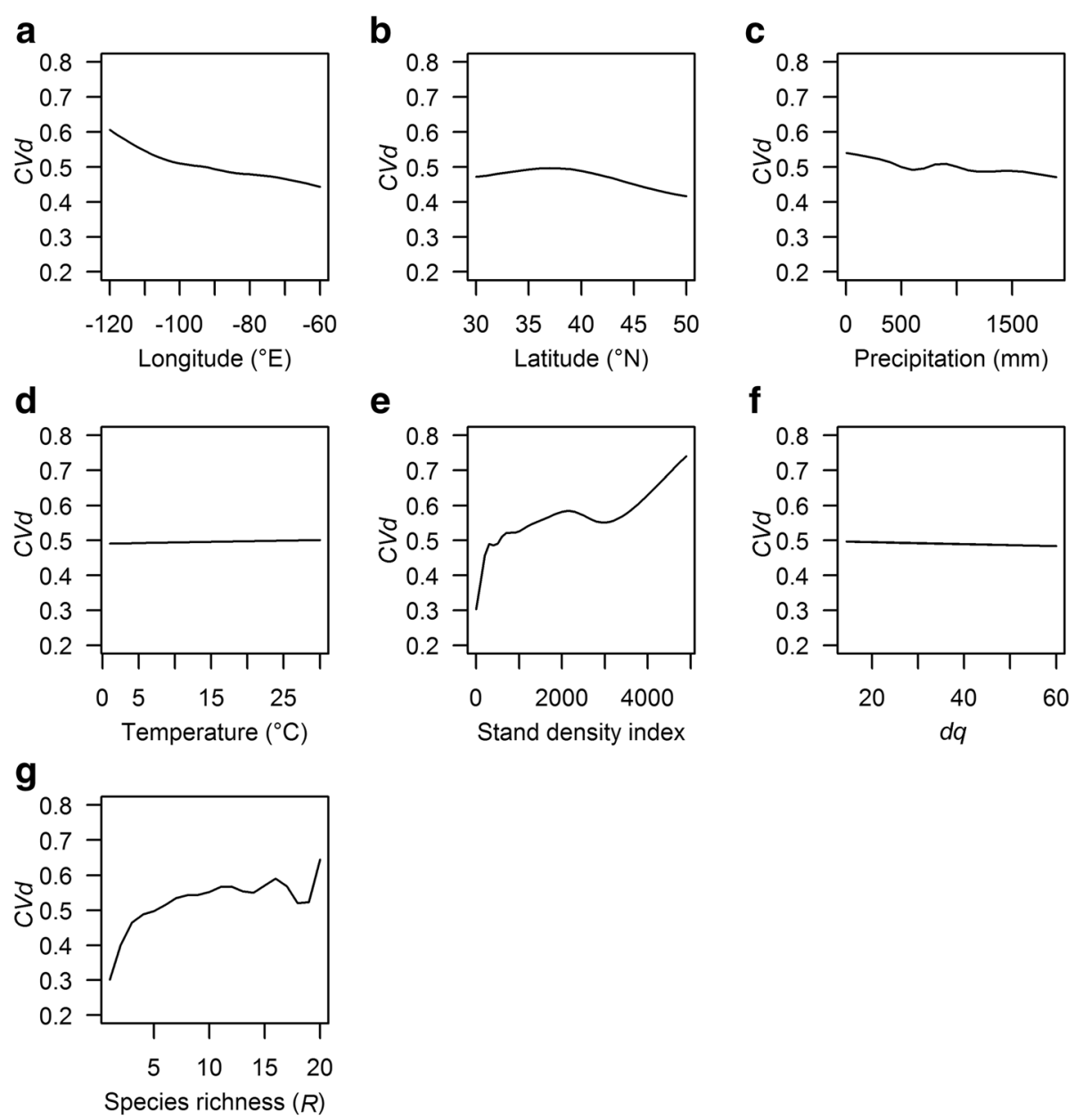

Fig. 7 Effects of longitude (a), latitude (b), annual precipitation $(\mathbf{c})$, mean annual temperature $(\mathbf{d})$, tree species richness $(\mathbf{e})$, and stand density $(\mathbf{f})$ on tree size heterogeneity of US inventory plots. Each variable was tested on its own while other variables were set to the mean

This would mean that Germany is located at the northern end of the gradient and adjacent to the USA. The lower number of tree species and temperatures in the German plots can lead to a lower structure while highly productive even-aged monoculture-type forest stands are still present with combined high productivity and low tree size heterogeneity. The forest stands in Germany are much longer and more intensively shaped by even-aged management (Paillet et al. 2010; Schall et al. 2017), while in the USA structural heterogeneity is still higher due to disturbances and climatic shifts (Oliver 1980; Dolanc et al. 2014; McIntyre et al. 2015).

\section{Climate}

Apart from the location which already explains a large part of the variation in stand productivity, climate played a major role. We found that a warm and dry climate can especially decrease stand productivity (QII) but only with regard to precipitation, which was a strong predictor of stand productivity, as the latter is restricted by lower annual precipitation. This trend has also been described by others (Toledo et al. 2011; Żywiec et al. 2017). We found that for both countries, there is an optimum amount of annual precipitation beyond which additional units of precipitation were rather counterproductive. In Germany this effect could come from large quantities of precipitation, especially in the mountain areas and along the coastline, with counterproductive effects due to a shorter vegetation period in the mountainous areas and strong winds along the coast (Friend and Woodward 1990; Pretzsch et al. 2015). In the USA, we also saw a similar pattern where the Pacific Coast was generally lower in forest productivity than was the Atlantic Coast, despite the Pacific's greater annual precipitation. Regardless of the differences in biomes and other underlying silvicultural and environmental factors, our findings of an optimum beyond which additional annual precipitation could not lead to a higher stand productivity supported the saturation effect inherent in the biodiversity-productivity relationship (Liang et al. 2015). 

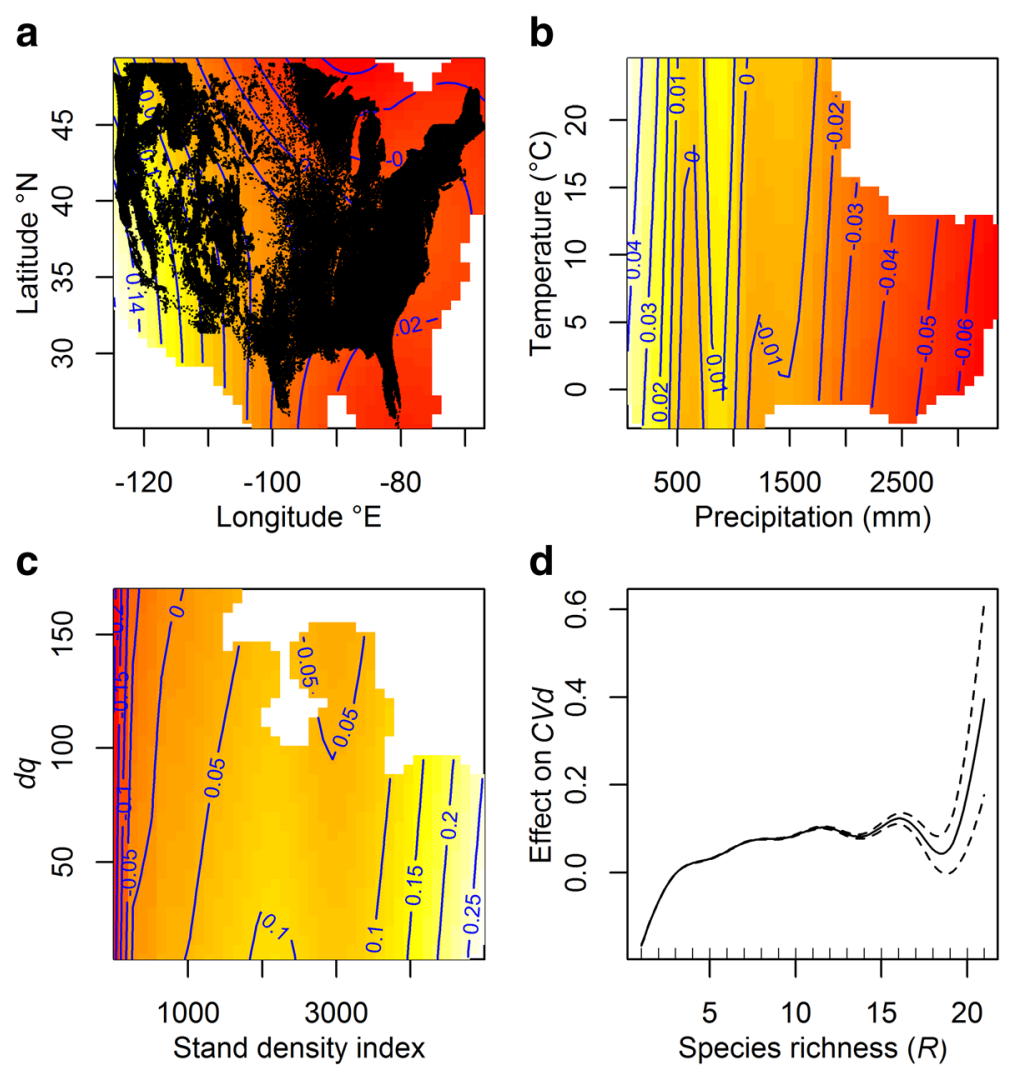

Fig. 8 Effects of location (a), climate (b), and stand density and tree species richness (c) on tree size heterogeneity of US inventory plots. Yellow = positive effect on productivity, red = negative effect on productivity. Blue contour lines show where the function has a constant value

Mean annual temperature's effect on stand productivity in Germany was opposite to those in the USA. Trees in the German inventory plots were benefiting from the warmer climate, whereas in the US plots, higher temperatures in combination with a low amount of precipitation were leading to lower growth rates. We speculate that the effects of temperature in the US could come from a less flexible situation of inventory plots, which are situated in

Table 3 Results of GAMs applied to inventory data from the USA

\begin{tabular}{|c|c|c|c|c|c|}
\hline & \multirow[b]{2}{*}{ Term } & \multicolumn{4}{|l|}{ USA } \\
\hline & & Intercept a & Std. error & Sig. & $R$-sq. (adj) \\
\hline \multirow[t]{4}{*}{$\overline{\mathrm{Q} / \mathrm{Q} \|}$} & $f_{1}($ Lon $\times$ Lat $)$ & 6.22 & 0.00 & $* * *$ & 0.90 \\
\hline & $f_{2}($ Precip $\times$ Temp $)$ & & & $* * *$ & \\
\hline & $f_{3}(R \times C V d)$ & & & $* * *$ & \\
\hline & $f_{4}(S D I \times d q)$ & & & $* * *$ & \\
\hline \multirow[t]{3}{*}{ QIII } & $f_{1}($ Lon $\times$ Lat $)$ & 0.44 & 0.00 & $* * *$ & 0.37 \\
\hline & $f_{2}($ Precip $\times$ Temp $)$ & & & $* * *$ & \\
\hline & $f_{3}(S D I \times R)$ & & & $* * *$ & \\
\hline
\end{tabular}

Lon longitude, Lat latitude, Precip annual precipitation, Temp mean annual temperature, $R$ species richness, $C V d$ coefficient of variation of diameter, SDI stand density index, $d q$ quadratic mean diameter $(\mathrm{cm})$. Sig. Significance values: 0 ***', $0.001^{\text {(**', }}, 0.01^{* * \prime}, 0.05$ regions where temperature cannot increase productivity anymore because trees, e.g., tropical trees, are already growing at their optimum temperature. Any additional temperature would be rather counter-productive (Way and Oren 2010). In Germany, trees are rather growing on sites below their temperature optimum, so a higher mean annual temperature consequently can lead to higher growth rates as compared to colder sites. Our speculation

Table 4 Results of GAMs applied to inventory data from Germany

\begin{tabular}{llllll}
\hline & & Germany & & & \\
\cline { 2 - 5 } & Term & Intercept a & Std. error & Sig. & $R$-sq. (adj) \\
\hline QI/QII & $f_{1}($ Lon $\times$ Lat $)$ & 12.24 & 0.04 & $* * *$ & 0.19 \\
& $f_{2}($ Precip $\times$ Temp $)$ & & & $* * *$ & \\
& $f_{3}($ R $\times$ CVd $)$ & & & $* * *$ & \\
& $f_{4}($ SDI $\times$ dq $)$ & & & $* * *$ & \\
QIII $\quad$ & $f_{1}($ Lon $\times$ Lat $)$ & 0.32 & 0.00 & $* * *$ & 0.29 \\
& $f_{2}$ (Precip $\times$ Temp $)$ & & & $* * *$ & \\
& $f_{3}($ SDI $\times R)$ & & & $* * *$ & \\
\hline
\end{tabular}

Lon longitude, Lat latitude, Precip annual precipitation, Temp mean annual temperature, $R$ species richness, $C V d$ coefficient of variation of diameter, SDI stand density index, $d q$ quadratic mean diameter $(\mathrm{cm})$. Sig. Significance values:

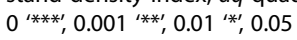


is supported by the acceleration of growth due to effects of the climate changes found in Europe (Pretzsch et al. 2014), as well as in boreal Canada (Wu et al. 2014), but not in the USA (Silva et al. 2010). Especially if higher temperatures occur in combination with higher amounts of precipitation, the effect on growth can be positive (Gustafson et al. 2017). Moreover, species traits, species composition, forest structure (Bohn and Huth 2017) and forest type (Vilà et al. 2013) determine how forest productivity is influenced by climate and could have shaped the relationships found in our study.

\section{Stand structure}

Finally, we also tested if water scarcity or low temperatures could enhance structural heterogeneity through the limitation of growth (QIII). Stand structure quantified by tree size heterogeneity was found to be highest in German plots with a high annual precipitation and high temperatures, and in US plots with low and intermediate amounts of annual precipitation.

Water limitation may foster the growth of small trees at the expense of their taller neighbors and reduce the size-asymmetry of competition. This phenomenon may be due to tall trees' being more exposed to the sun in sites with low water availability, especially during dry years. The tall trees close their stomata earlier and cannot make longer use of their preferential access to light. In contrast, under warm and dry conditions, the small trees in contrast may be less affected by or may even benefit from the reduced water consumption of their taller neighbors. So, the growth partitioning between the trees in stands on water-limited sites may favor the smaller members of the population, keeping them in the play, thereby fostering the diameter variation and structural heterogeneity (Pretzsch et al. 2012).

In both the German and the US plots, with more species, more structural heterogeneity was found. This effect could potentially result from the different allometry and functions of tree species, so that niches could be filled with a certain species, thereby creating more stand structure. Also, stand density was positively correlated with structure. These trends are well described in the European and AngloAmerican literature (Zeide 2001; Pretzsch 2005).

Considering that species richness fosters structural heterogeneity and structure, which, in turn can increase stand productivity even more, the combination of tree species richness and structure would be recommended while keeping in mind that other ecosystem services also benefit from species richness and structure, e.g., stability and the distribution of risk. Furthermore, a characterization of forest stands by species can still result in different outputs (all ecosystem goods and services) depending on regional peculiarities or the genetic variation of each species (Boyden et al. 2008). Higher productivity in mixed stands could be related to the species' traits more than to tree diversity in general (Jacob et al. 2010). Forming groups of species according to their functional traits rather than their taxonomy could, therefore, be useful. Analyzing the effect of species richness on stand productivity, as done in this study, could then potentially yield much clearer results, as the effects may not be hidden by intra-specific variation in traits.

\section{Methods}

Applying GAM models to large data sets, as performed in our study, will automatically lead to high significance values, which mean that the interpretation of $p$-values should be completed by analyzing the single effects of each variable. The size of the effect of each independent variable on the dependent variable must still be tested to estimate if the effect is only a slight trend. The major problem in our analysis was the use of different methods to obtain productivity values for each plot in Germany and the US. Conducting large inventories such as the one in the USA is an expensive endeavor and not all sample plots can be measured regularly. If productivity on inventory plots is calculated only for the ones measured more often and interpolated to all the other inventory plots, very different plots can become assigned to the similar productivity value. The variation in productivity as a dependent variable may then not be large enough to be explained by variables other than location or climate. Considering that the effects of species richness and structure on productivity in our model can only be very small, we can still take them seriously and interpret their trends. The US inventory data can be expected to comprise a comparable high degree of inexplicable variation due to the method of estimating and interpolating productivity.

Including successional stages through stand age would have been useful as well but no reliable data was available as the stand ages given in the inventories were roughly estimated without considering the different ages of the different layers. Therefore, we used $S D I$ and tree size to cover the potential effects of development stages. Assuming that a higher stand density results from a higher number of smaller trees that yield higher relative growth rates and a lower stand density can be explained by fewer larger trees with a lower relative growth (Caspersen et al. 2011), our model promotes the choice of $S D I$ as a substitute for the lack of information on stand age. Analyzing the relationship of structure, species mixing and productivity along the developmental stages in terms of stand age could be a worthwhile study for the future.

\section{Conclusion}

Our results do not include aspects such as the stability, resilience or biodiversity of other plant species other 
than trees. Our study focused on productivity and tree species richness rather than overall ecosystem productivity and biodiversity. However, knowing how tree species richness, structure and productivity are correlated helps us understand the whole forest ecosystem. Apart from climate and site conditions, tree species richness can be the most important driver for productivity. Hence, biodiversity and productivity can complement each other and enable the provision of multiple forest ecosystem goods and services. In the case of a negative structureproductivity relationship, as found in the German inventory plots, in combination with the need for forest structure (e.g., as a stabilizing function or for the aim of conservation), species richness can mitigate the potentially negative effects of structure on stand productivity. In our case, favoring forest stands with more than four species over monocultures would be a solution for the trade-off of combining structural heterogeneity and high yields. In the case of a positive structure-productivity relationship, as found in the US inventory plots, an increase in structural heterogeneity implies a boost in productivity while enhancing other structure-related forest ecosystem functions. All in all, there is no need to disapprove of structural heterogeneity, because a combination of high productivity and the benefits of a structurally diverse stand can be achieved.

Knowing the climatic influence on productivity, e.g., an optimum range of precipitation where productivity peaks, can help to adjust forest management to the expected climatic conditions of the future. This knowledge could be especially valuable for estimating the consequences of shifting climatic conditions for a forest ecosystem that includes certain species and is already located in its optimum range of precipitation and temperature or is at the border of a climatic zone.

The collection and use of global inventory data will enable big data research to contribute to better management and use of forest ecosystems worldwide, as well as to find out more about the relationships between the different characteristics of a forest. The major problems faced by this study when using inventory data were the different ways of achieving productivity values, which led to partly vague model outcomes. The more often national inventories are conducted, the more precisely can volume increment, and consequently, stand productivity, be calculated. On the downside, conducting forest inventories is cost intensive, especially if much detailed information must be collected frequently. Therefore, the collection and combination of worldwide inventory data as done by GFBI is crucial and will help research conducted on forest ecosystems be easier, more universal, and more efficient.

\section{Acknowledgements}

This study has been supported in parts by the BiodivERsA project, "GreenFutureForests" (\#01LC1610B), the FORD project Biotip (\#01LC1716D) promoted by the German Aerospace Center (DLR) and the Federal Ministry of Education and Research, the project Sumforest - REFORM Risk Resilient Forest Management (\#2816ERA02S), and by the West Virginia University, and the USDA McIntire-Stennis Funds WVA00126. We thank the Global Forest Biodiversity Initiative for establishing the data standards and collaborative framework. The first and third authors also thank the Bavarian State Ministry of Nutrition, Agriculture, and Forestry for permanent support of the project W 07 "Long-term experimental plots for forest growth and yield research" (\#7831-22209-2013)

\section{Authors' contributions}

$\mathrm{LZ}$ and $J$ compiled the US inventory data sets and conducted big data analysis. HP established the direction and hypothesis of the study, as well as contributed to the interpretation of the results. $L Z$ drafted the manuscript, conducted data preparation and statistical analyses. All authors contributed to the writing of the manuscript. All authors read and approved the final manuscript.

\section{Competing interests}

The authors declare that they have no competing interests.

\section{Author details}

${ }^{1}$ Center of Life and Food Sciences Weihenstephan, Technical University of Munich, Hans-Carl-von-Carlowitz-Platz 2, 85354 Freising, Germany. ${ }^{2}$ Division of Forestry and Natural Resources, Davis College of Agriculture, Natural

Resources \& Design, West Virginia University, 340 Percival Hall, Morgantown, W 26506-6108, USA.

Received: 21 July 2017 Accepted: 20 December 2017

Published online: 11 February 2018

\section{References}

Ammer C (2008) Converting Norway spruce stands with beech - a review of arguments and techniques. Austr J Forest Sci 125:3-26

Binkley D (1984) Importance of size-density relationships in mixed stands of douglas-fir and red alder. For Ecol Manag 9:81-85

BMEL - Bundesministerium for Ernährung und Landwirtschaft (2014) Der Wald in Deutschland. Ausgewählte Ergebnisse der dritten Bundeswaldinventur, Berlin

Bohn FJ, Huth A (2017) The importance of forest structure to biodiversityproductivity relationships. The Royal Society. https://doi.org/10.1098/rsos. 160521

Boivenue C, Running S (2006) Impacts of climate change on natural forest productivity - evidence since the middle of the 20th century. Glob Chang Biol 12:862-882

Bourdier T, Cordonnier T, Kunstler G, Piedallu C, Lagarrigues G, Courbaud B (2016) Tree size inequality reduces forest productivity: an analysis combining inventory data for ten European species and a light competition model. PLoS One 11:e0151852

Boyden S, Binkley D, Stape JL (2008) Competition among eucalyptus trees depends on genetic variation and resource supply. Ecology 89:2850-2859

Caspersen JP, Vanderwel MC, Cole WG, Purves DW (2011) How stand productivity results from size- and competition-dependent growth and mortality. PLoS One 6:e28660

Chen HYH, Klinka K (2003) Aboveground productivity of western hemlock and western redcedar mixed-species stands in southern coastal British Columbia. For Ecol Manag 184:55-64

Chertov O (2010) Impact of temperature increase and precipitation alteration at climate change on forest productivity and soil carbon in boreal forest ecosystems in Canada and Russia: simulation approach with the EFIMOD model. In: Rodriguez-Morales A, Risquez A, Echezuria $L$ (eds) Impact of climate change on health and disease in Latin America. InTech Open Access Publisher, London

Crawley MJ (2007) The R book. John Wiley \& Sons, Ltd, Chichester, UK

Danescu A, Albrecht AT, Bauhus J (2016) Structural diversity promotes productivity of mixed, uneven-aged forests in southwestern Germany. Oecologia 182:319-333

R Development Core Team (2008) R: A language and environment for statistical computing, Vienna. http://www.R-project.org. Accessed 15 July 2017

Dieler J (2013) Biodiversität und Waldbewirtschaftung - Auswirkungen auf Artenvielfalt, Strukturdiversität und Produktivität. Tagungsband der Sektion Ertragskunde, DVFFA, pp 25-34 
Dieler J, Uhl E, Biber P, Müller J, Rötzer T, Pretzsch H (2017) Effect of forest stand management on species composition, structural diversity, and productivity in the temperate zone of Europe. Eur J Forest Res. https://doi.org/10.1007/ s10342-017-1056-1

Dolanc CR, Safford HD, Thorne JH, Dobrowski SZ (2014) Changing forest structure across the landscape of the sierra Nevada, CA, USA, since the 1930s. Ecosphere 5:art101

Edgar CB, Burk TE (2001) Productivity of aspen forests in northeastern Minnesota, U.S.A., as related to stand composition and canopy structure. Can J For Res 31:1019-1029

Fick SE, Hijmans RJ (2017) WorldClim 2: new 1-km spatial resolution climate surfaces for global land areas. Int J Climatol 21:455

Friend AD, Woodward FI (1990) Evolutionary and ecophysiological responses of mountain plants to the growing season environment. In: Fitter A, Macfadyen A, Begon M (eds) Advances in ecological research, vol 20. Academic Press, New York, pp 59-124

Gamfeldt L, Snäll T, Bagchi R, Jonsson M, Gustafsson L, Kjellander P, Ruiz-Jaen MC Froberg M, Stendahl J, Philipson CD, Mikusinski G, Andersson E, Westerlund B, Andren H, Moberg F, Moen J, Bengtsson J (2013) Higher levels of multiple ecosystem services are found in forests with more tree species. Nat Commun 4:1340

Global Forest Biodiversity Initiative (2016) People, nature, world, diversity. http:// www.gfbinitiative.org/. Accessed 15 July 2017

Gustafson EJ, Miranda BR, De Bruijn AMG, Sturtevant BR, Kubiske ME (2017) Do rising temperatures always increase forest productivity? Interacting effects of temperature, precipitation, cloudiness and soil texture on tree species growth and competition. Environm Model Software 97:171-183

Hakkenberg CR, Song C, Peet RK, White PS, Rocchini D (2016) Forest structure as a predictor of tree species diversity in the North Carolina piedmont. J Veg Sci 27:1151-1163

Henning P (2016) Die Bundeswaldinventur in der Geodateninfrastruktur des Thünen-Instituts. https://bwi.info/Download/de/BWI-Basisdaten/ThuenenGDI/ BundeswaldinventurInDerGeodateninfrastrukturDesThuenenInstitutes.pdf. Accessed 15 July 2017

Ishii HT, Tanabe S, Hiura T (2004) Exploring the relationships among canopy structure, stand productivity, and biodiversity of temperate forest ecosystems. For Sci 50:342-355

Jacob M, Leuschner C, Thomas FM (2010) Productivity of temperate broad-leaved forest stands differing in tree species diversity. Ann Forest Sci 67:503

Kelty MJ (2006) The role of species mixtures in plantation forestry. For Ecol Manag 233:195-204

Knoke T, Ammer C, Stimm B, Mosandl R (2008) Admixing broadleaved to coniferous tree species: a review on yield, ecological stability and economics. Eur J Forest Res 127:89-101

Liang J, Crowther TW, Picard N, Wiser S, Zhou M, Alberti G, Schulze ED, McGuire AD, Bozzato F, Pretzsch $H$, de-Miguel S, Paquette A, Herault B, SchererLorenzen M, Barrett CB, Glick HB, Hengeveld GM, Nabuurs GJ, Pfautsch S, Viana H, Vibrans AC, Ammer C, Schall P, Verbyla D, Tchebakova N, Fischer M, Watson JV, HYH C, Lei XD, Schelhaas MJ, Lu HC, Gianelle D, Parfenova El, Salas C, Lee E, Lee B, Kim HS, Bruelheide H, Coomes DA, Piotto D, Sunderland T, Schmid B, Gourlet-Fleury S, Sonke B, Tavani R, Zhu J, Brandl S, Vayreda J, Kitahara F, Searle EB, Neldner VJ, Ngugi MR, Baraloto C, Frizzera L, Balazy R, Oleksyn J, Zawila-Niedzwiecki T, Bouriaud O, Bussotti F, Finer L, Jaroszewicz B, Jucker T, Valladares F, Jagodzinski AM, Peri PL, Gonmadje C, Marthy W, O'Brien T, Martin EH, Marshall AR, Rovero F, Bitariho R, Niklaus PA, Alvarez-Loayza P, Chamuya N, Valencia R, Mortier F, Wortel V, Engone-Obiang NL, Ferreira LV, Odeke DE, Vasquez RM, Lewis SL, Reich PB (2016) Positive biodiversity-productivity relationship predominant in global forests. Science 354:aaf8957

Liang J, Zhou M, Tobin PC, McGuire AD, Reich PB (2015) Biodiversity influences plant productivity through niche-efficiency. Proc Natl Acad Sci U S A 112: 5738-5743

Lindenmayer D, Messier C, Sato C (2016) Avoiding ecosystem collapse in managed forest ecosystems. Front Ecol Environ 14:561-568

Lokers R, Knapen R, Janssen S, van Randen Y, Jansen J (2016) Analysis of big data technologies for use in agro-environmental science. Environm Model Software 84:494-504

Luu TC, Binkley D, Stape JL (2013) Neighborhood uniformity increases growth of individual eucalyptus trees. For Ecol Manag 289:90-97

McIntyre PJ, Thorne JH, Dolanc CR, Flint AL, Flint LE, Kelly M, Ackerly DD (2015) Twentieth-century shifts in forest structure in California: denser forests, smaller trees, and increased dominance of oaks. Proc Natl Acad Sci U S A 112(5):1458-1463

MCPFE (1993) Resolution Hl: general guidelines for the sustainable management of forests in Europe. Proceedings of the 2nd ministerial conference on the protection of forests in Europe, Helsinki. http://www.foresteurope.org/docs/ MC/MC_helsinki_resolutionH1.pdf. Accessed 2 Jan 2018

Morin X, Fahse L, de Mazancourt C, Scherer-Lorenzen M, Bugmann H (2014) Temporal stability in forest productivity increases with tree diversity due to asynchrony in species dynamics. Ecol Lett 17:1526-1535

O'Connell BM, LaPoint EB, Turner JA, Ridley T, Pugh SA, Wilson AM, Waddell KL, Conkling BL (2014) FIA database description and user guide for phase 2: version: 6.0.1. https://www.fia.fs.fed.us/library/database-documentation/ current/ver60/FIADB\%20User\%20Guide\%20P3_6-0-1_final.pdf. Accessed 2 Jan 2018

Oliver CD (1980) Forest development in North America following major disturbances. For Ecol Manag 3:153-168

Paillet $Y$, Bergès L, Hiältén J, Odor $P$, Avon C, Bernhardt-Römermann M, Bijlsma RJ, De Bruyn L, Fuhr M, Grandin U, Kanka R, Lundin L, Luque S, Magura T, Matesanz S, Meszaros I, Sebastia MT, Schmidt W, Standovar T, Tothmeresz B, Uotila A, Valladares F, Vellak K, Virtanen R (2010) Biodiversity differences between managed and unmanaged forests: meta-analysis of species richness in Europe. Conserv Biol J Soc Conserv Biol 24:101-112

Paquette A, Messier C (2011) The effect of biodiversity on tree productivity: from temperate to boreal forests. Glob Ecol Biogeogr 20:170-180

Pretzsch H (2005) Stand density and growth of Norway spruce (Picea abies (L.) Karst.) and European beech (Fagus sylvatica L.): evidence from long-term experimental plots. Eur J Forest Res 124:193-205

Pretzsch H (2009) Forest dynamics, growth and yield: from measurement to model. Springer, Berlin

Pretzsch H, Biber P (2016) Tree species mixing can increase maximum stand density. Can J For Res 46:1179-1193

Pretzsch H, Biber P, Schütze G, Uhl E, Rötzer T (2014) Forest stand growth dynamics in Central Europe have accelerated since 1870. Nat Commun 5:4967

Pretzsch H, Biber P, Uhl E, Dauber E (2015) Long-term stand dynamics of managed spruce-fir-beech mountain forests in Central Europe: structure, productivity and regeneration success. Forestry 88:407-428

Pretzsch H, del Río M, Ammer C, Avdagic A, Barbeito I, Bielak K, Brazaitis G, Coll L, Dirnberger G, Drossler L, Fabrika M, Forrester D, Godvod K, Heym M, Hurt V, Kurylyak V, Lof M, Lombardi F, Matovic B, Mohren F, Motta R, den Ouden J, Pach M, Ponette Q, Schutze G, Schweig J, Skrzyszewski J, Sramek V, Sterba H, Stojanovic D, Svoboda M, Vanhellemont M, Verheyen K, Wellhausen K, Zlatanov T, Bravo-Oviedo A (2015) Growth and yield of mixed versus pure stands of Scots pine (Pinus sylvestris L.) and European beech (Fagus sylvatica L.) analysed along a productivity gradient through Europe. Eur J Forest Res 134:927-947

Pretzsch H, Dieler J, Rötzer T (2012) Principles of growth partitioning between trees in forest stands under stress. In: Matyssek R, Schnyder H, Osswald W, Ernst D, Munch JC, Pretzsch H (eds) Growth and Defence in plants. Springer Berlin Heidelberg, Berlin Heidelberg, pp 311-329

Pretzsch H, Forrester DI, Bauhus J (2017) Mixed-species forests: ecology and management. Springer, Berlin, p 653

Puettmann KJ, Coates KD, Messier C (2009) A critique of silviculture: managing for complexity. Island Press, Washington DC

Puettmann KJ, Wilson SM, Baker SC, Donoso PJ, Drössler L, Amente G, Harvey BD, Knoke T, Lu Y, Nocentini S, Putz FE, Yoshida T, Bauhus J (2015) Silvicultural alternatives to conventional even-aged Forest management - what limits global adoption? Forest. Ecosystems 2:8

Reineke LH (1933) Perfecting a stand-density index for even-aged forests. J Agricult Res 46:627-638

Schall P, Gossner MM, Heinrichs S, Fischer M, Boch S, Prati D, Jung K, Baumgartner V, Blaser S, Böhm S, Buscot F, Daniel R, Goldmann K, Kaiser K, Kahl T, Lange M, Müller J, Overmann J, Renner SC, Schulze ED, Sikorski J, Tschapka M, Türke M, Weisser WW, Wemheuer B, Wubet T, Ammer C (2017) The impact of even-aged and uneven-aged forest management on regional biodiversity of multiple taxa in European beech forests. J Appl Ecol 109:17495

Schröter D, Cramer W, Leemans R, Prentice IC, Araújo MB, Arnell NW, Bondeau A Bugmann H, Carter TR, Gracia CA, de la Vega-Leinert AC, Erhard M, Ewert F, Glendining M, House Jl, Kankaanpaa S, Klein RJT, Lavorel S, Lindner M, Metzger MJ, Meyer J, Mitchell TD, Reginster I, Rounsevell M, Sabate S, Sitch S, 
Smith B, Smith J, Smith P, Sykes MT, Thonicke K, Thuiller W, Tuck G, Zaehle S, Zierl B (2005) Ecosystem service supply and vulnerability to global change in Europe. Science (New York, NY) 310:1333-1337

Silva LCR, Anand M, Leithead MD (2010) Recent widespread tree growth decline despite increasing atmospheric $\mathrm{CO}_{2}$. PLoS One 5:e11543

Silva Pedro M, Rammer W, Seidl R, Roxburgh S (2017) Disentangling the effects of compositional and structural diversity on forest productivity. J Veg Sci 28:649-658

Soares AAV, Leite HG, Souza AL, Silva SR, Lourenço HM, Forrester DI (2016) Increasing stand structural heterogeneity reduces productivity in Brazilian eucalyptus monoclonal stands. For Ecol Manag 373:26-32

The Montréal Process (2015) Criteria and indicators for the conservation and sustainable Management of Temperate and Boreal Forests. http: www.mpci. org. Accessed 15 July 2017

Toledo M, Poorter L, Peña-Claros M, Alarcón A, Balcázar J, Leaño C, Licona JC, Llanque O, Vroomans V, Zuidema P, Bongers F (2011) Climate is a stronger driver of tree and forest growth rates than soil and disturbance. J Ecol 99:254-264

Uhl E, Biber P, Ulbricht M, Heym M, Horváth T, Lakatos F, Gál J, Steinacker L, Tonon G, Ventura M, Pretzsch H (2015) Analysing the effect of stand density and site conditions on structure and growth of oak species using Nelder trials along an environmental gradient: experimental design, evaluation methods, and results. Forest Ecosyst 2:17

Vilà M, Carrillo-Gavilán A, Vayreda J, Bugmann H, Fridman J, Grodzki W, Haase J, Kunstler G, Schelhaas M, Trasobares A (2013) Disentangling biodiversity and climatic determinants of wood production. PLoS One 8:e53530

Wang J, Cheng Y, Zhang C, Zhao Y, Zhao X, von Gadow K (2016) Relationships between tree biomass productivity and local species diversity. Ecosphere. https://doi.org/10.1002/ecs2.1562

Way DA, Oren R (2010) Differential responses to changes in growth temperature between trees from different functional groups and biomes: a review and synthesis of data. Tree Physiol 30:669-688

Wohlgemuth T (2015) Climate change and tree responses in central European forests. Ann Forest Sci 72:285-287

Wood SN (2011) Fast stable restricted maximum likelihood and marginal likelihood estimation of semiparametric generalized linear models. J Roy Stat Soc (B) 73:3-36

UN General Assembly (1987) Our common future. Report of the World Commission on Environment and Development.

Wu C, Hember RA, Chen JM, Kurz WA, Price DT, Boisvenue C, Gonsamo A, WM J (2014) Accelerating forest growth enhancement due to climate and atmospheric changes in British Colombia, Canada over 1956-2001. Sci Rep 4:4461

Yang Y (2005) Factors affecting forest growth and possible effects of climate change in the Taihang Mountains, northern China. Forestry 79:135-147

Zeide B (2001) Thinning and growth: a full turnaround. J Forest 99:20-25

Zuur AF (2009) Mixed effects models and extensions in ecology with R (statistics for biology and health). Springer, New York

Żywiec M, Muter E, Zielonka T, Delibes M, Calvo G, Fedriani JM (2017) Long-term effect of temperature and precipitation on radial growth in a threatened thermo-Mediterranean tree population. Trees-Struct Funct 31:491-501

\section{Submit your manuscript to a SpringerOpen ${ }^{\circ}$ journal and benefit from:}

- Convenient online submission

- Rigorous peer review

- Open access: articles freely available online

- High visibility within the field

- Retaining the copyright to your article 